Clinica Chimica Acta, 65 (1975) 157-165

(c) Elsevier Scientific Publishing Company, Amsterdam - Printed in The Netherlands

CCA 7275

\title{
A NEW VARIANT OF GLUCOSEPHOSPHATE ISOMERASE DEFICIENCY (GPI-UTRECHT)
}

\author{
J.P.G.M. VAN BIERVLIET ${ }^{a}$, L. VAN MILLIGEN-BOERSMA ${ }^{b}$ and G.E.J. STAAL ${ }^{\mathbf{b}, *}$ \\ ${ }^{a}$ University Children's Hospital, Het Wilhelmina Kinderziekenhuis, Utrecht, and \\ ${ }^{\mathrm{b}}$ Section of Medical Enzymology, Department of Hematology, State University Hospital, \\ Utrechl (The Netherlands)
}

(Received April 29, 1975)

\section{Summary}

A new case of glucosephosphate isomerase deficiency is described in a Dutch family. The activity of the enzyme was decreased to $20-25 \%$ of the normal value. Characterization of the defect enzyme showed a pronounced thermolability. Heating of the enzyme at $45^{\circ} \mathrm{C}$ showed a loss of activity of $90 \%$ after one hour. The $\mathrm{pH}$-optimum and the electrophoretic migration were normal. The $K_{\mathrm{m}}$-value for F-6-P, the $K_{\mathrm{i}}$ for the competitive inhibitors 2,3-DPG and 6-PG were in the normal range. The variant described here differs from all known variants. Therefore we propose to give to this new variant the name of GPI-Utrecht.

\section{Introduction}

Glucosephosphate isomerase (EC 5.3.1.9) (GPI) catalyses the reversible interconversion of glucose 6-phosphate and fructose 6-phosphate (F-6-P). In 1968 Baughan et al. [1] reported that GPI-deficiency is a cause of hemolytic nonspherocytic anemia. Since then more than 17 distinct deficient GPI variants have been published [2-7]. GPI-deficiency is after glucose-6-phosphate dehydrogenase- and pyruvate kinase deficiency probably the most common enzyme defect in human erythrocytes. Distinct GPI variants were described, based on differences in electrophoretic migration, the extent of thermal inactivation, pH-isoelectric point, GPI activity, pH-optimum, molecular weight and antibody combining capacity. In this paper we deal with a new variant detected in a Dutch family. It is proposed to give it the name of GPI-Utrecht.

\footnotetext{
* Correspondence to Dr. G.E.J. Staal.
} 


\section{Case report}

An $8 \frac{1}{2}$ year old, mentally retarded girl was admitted to our hospital in July 1974, for observation of a severe hemolytic anemia and jaundice. Since birth she was suffering from a severe non-classified non-spherocytic hemolytic disorder. Besides chronic hemolysis, hemolytic crises were provoked by frequently occurring bacterial and viral infections and also by the administration of pharmaca (a.o. nitrofurantoin, acetylsalicylic acid, anesthetics, phenothiazines). The splenectomy performed in 1972, however, did not influence the course of the hemolytic disorder. A few days before referral to our hospital the patient inadvertently received nitrofurantoin for treatment of a urinary infection. This might have provoked hemolytic crises, observed at admission.

\section{Materials and methods}

Substrates, coenzymes and auxiliary enzymes for the determination of enzymes and glycolytic intermediates were provided by Boehringer and Sohne (Mannheim). All other reagents used were of analytical grade. Glycolytic intermediates (except for adenosine triphosphate (ATP) and 2,3-diphosphoglycerate (2,3-DPG) were determined according to Niessner and Beutler [8] . Adenosine triphosphate (ATP) was determined according to Minakami et al. [9] and 2,3-DPG according to Sigma [10]. Glucosephosphate isomerase activity was measured by the method of Slein [11] at $25^{\circ} \mathrm{C}$. The reduction of NADP was followed at $340 \mathrm{~nm}$ with a Perkin-Elmer spectrophotometer. GPI activity was determined in $0.1 \mathrm{M}$ Tris/ $\mathrm{HCl}, \mathrm{pH} 8.3$, in a final volume of $3 \mathrm{ml}$ containing $3 \mathrm{mM}$ F-6-P, $0.5 \mathrm{mM}$ NADP, $0.01 \mathrm{ml}$ glucose-6-phosphate dehydrogenase and sample. GPI from erythrocytes was purified according to the method of Arnold et al. [12]. Homogenization of liver, muscle tissue and leucocytes was carried out in $0.1 \mathrm{M}$ sodium potassium phosphate buffer, $\mathrm{pH}$ 7.0 , containing $0.1 \%$ saponine. Leucocytes were obtained by the method of Wyss et al. [13]. The protein content was determined by the method of Lowry et al. [14] with crystalline human serum albumin as standard. Electrophoresis was carried out according to Meera Khan and Ratazzi [15] and staining for GPI after electrophoresis according to Welch [16].

\section{Results}

As would be expected in patients with high reticulocyte counts, normal or increased activities were found for the erythrocytary enzymes of the glycolytic pathway (phosphofructokinase, triosephosphate isomerase, glyceraldehyde-3phosphate dehydrogenase, phosphoglycerate kinase, enolase, pyruvate kinase, lactate dehydrogenase), the hexosemonophosphate pathway, the glutathione metabolism (glucose-6-phosphate dehydrogenase, 6-phosphogluconate dehydrogenase, glutathione reductase, glutathione peroxidase) and catalase. The glucose-6-phosphate isomerase activity, however, was found to be $6.4 \mu \mathrm{mol} /$ $\mathrm{min} / \mathrm{g} \mathrm{Hb}$, a value of $20-25 \%$ of the normal value $(28-36 \mu \mathrm{mol} / \mathrm{min} / \mathrm{g} \mathrm{Hb})$. Compared to normal control tissues the enzyme activity in leucocytes, thrombocytes, liver- and muscle tissues from the proband was decreased to the same 
TABLE I

ACTIVITY OF GLUCOSE-6-PHOSPHATE ISOMER ASE IN DIFFERENT TISSUES

\begin{tabular}{ll}
\hline & Percentage of normal activity \\
\hline Erythrocytes & $20-25$ \\
Leucocytes & 25 \\
Thrombocytes & 20 \\
Liver & 26 \\
Musele & 28 \\
\hline
\end{tabular}

degree (see Table I). In both parents the GPI activity of the erythrocytes was decreased to $50 \%$ of the normal activity. Table II shows the content of glycolytic intermediates in erythrocytes. In agreement with GPI-deficiency, the glucose 6-phosphate concentration is increased while the other metabolites of glycolysis are in the low normal range.

\section{Characterization of the defective enzyme}

\section{Heat stability}

One of the most characteristic findings in GPI-deficiency is the increased thermolability of the defective enzyme [2]. Fig. 1 shows the influence of heating for the normal- and defective enzyme (isolated from erythrocytes) at $45^{\circ} \mathrm{C}$. In the patient's enzyme $90 \%$ of its activity is lost after one hour heating (Fig. 1B) while only $10 \%$ decrease of GPI activity is noticed for the normal control (Fig. 1A). The same pattern was found, when instead of the purified enzyme a hemolysate was used. These results prove the existence of the marked thermolability of the defective enzyme. In contrast to the patient's enzyme, the parental erythrocytes contained the same small amount of heat-labile GPI activity.

\section{TABLE II}

THE CONTENT OF GLYCOLYTIC INTERMEDIATES FROM NORMAL AND THE PATIENT'S ER YTHROCYTES

Figures expressed as nmol/ml erythrocytes, except for ATP and $2,3-\mathrm{DPG}$ ( $\mu \mathrm{mol} / \mathrm{ml}$ erythrocytes).

\begin{tabular}{lrc} 
& Normal & Patient \\
\hline Glucose 6-phosphate & $30-45$ & 72 \\
Fructose 6-phosphate & $10-20$ & 13 \\
Glyceraldehyde phosphate & $2-10$ & 2 \\
Dihydroxyacetone phosphate & $10-22$ & 11 \\
Fructose 1,6-diphosphate & $3-13$ & 3 \\
3-Phosphoglycerate & $40-90$ & 44 \\
Phosphoenolpyruvate & $10-24$ & 10 \\
2-Phosphoglycerate & $4-14$ & 6 \\
Pyruvate & $50-200$ & 60 \\
Adenosine triphosphate & $1.2-1.6$ & 1.2 \\
2,3-Diphosphoglycerate & $5.3 \pm 0.4$ & 4.9 \\
\hline
\end{tabular}



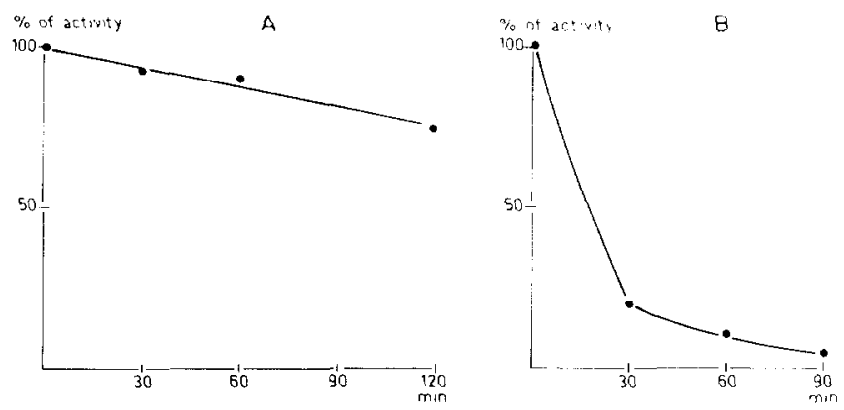

Fig. 1. Heat stability test for the normal (A) and the patient's GPI (B). The experiment was performed at $45^{\circ} \mathrm{C}$ in $5 \times 10^{-2} \mathrm{M}$ TRA-buffer, pH $7.2+10 \mathrm{mM}$ EDTA.

\section{pH-optimum and electrophoresis}

Fig. 2 shows the pH optimum for the normal and the defective enzyme. No difference in $\mathrm{pH}$ optimum is observed. In both cases the same value was found ( $\mathrm{pH}$ optimum: 8.3). The electrophoretic migrations of the patient's enzyme from different tissues is compared to normal controls in Fig. 3. In these it can be seen that the electrophoretic migration of GPI from muscle, leucocyte and erythrocyte in the patient is the same as normal controls.

A narrow single band is present in the patient's zymogram and a broad single band in the zymogram of the normals. As presumed by Blackburn et al. [17] the minor bands observed sometimes in zymograms of normal GPI [18] are probably artefacts arising from oxidation of the enzyme. The electrophoretic migration of the parent's erythrocyte enzyme was normal. The width of the bands in the parents was intermediate between those of the patients and the normals.

\section{Kinetics}

Figs. $4 \mathrm{~A}$ and $4 \mathrm{~B}$ show the $1 / v$ versus $1 /[\mathrm{F}-6 \cdot \mathrm{P}]$, plot at $37^{\circ} \mathrm{C}$ of the enzyme isolated from normal erythrocytes (Fig. $4 \mathrm{~A}$ ) and from the patient's
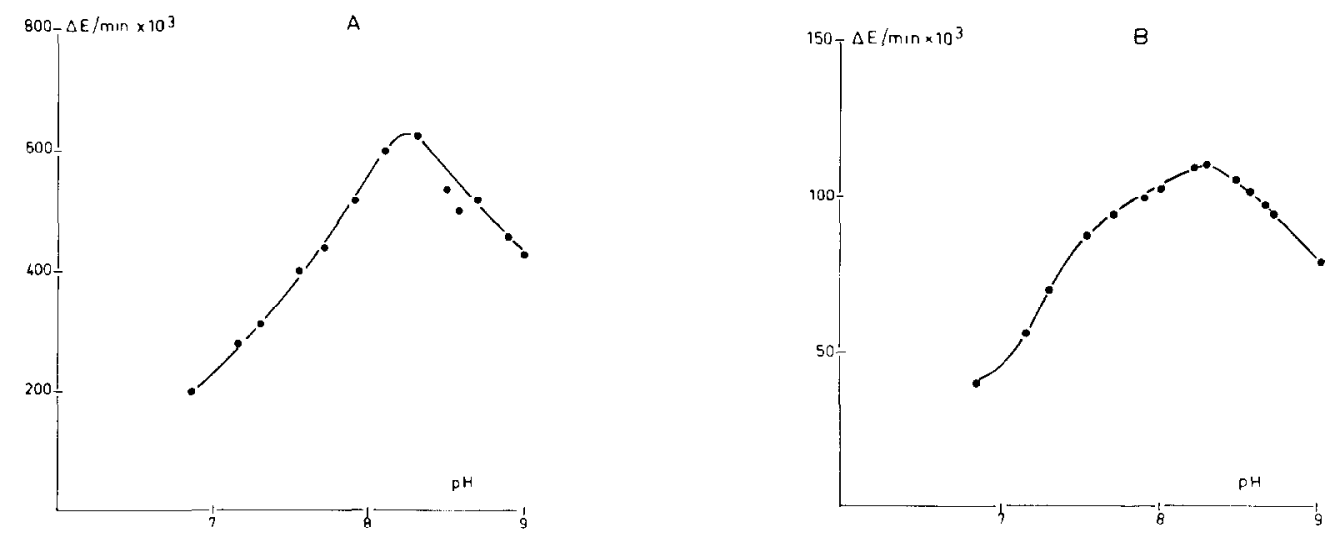

Fig. 2. pH optimum for the normal (A) and the patient's enzyme (B). Buffer used: $0.2 \mathrm{M}$ Tris/HCl. 


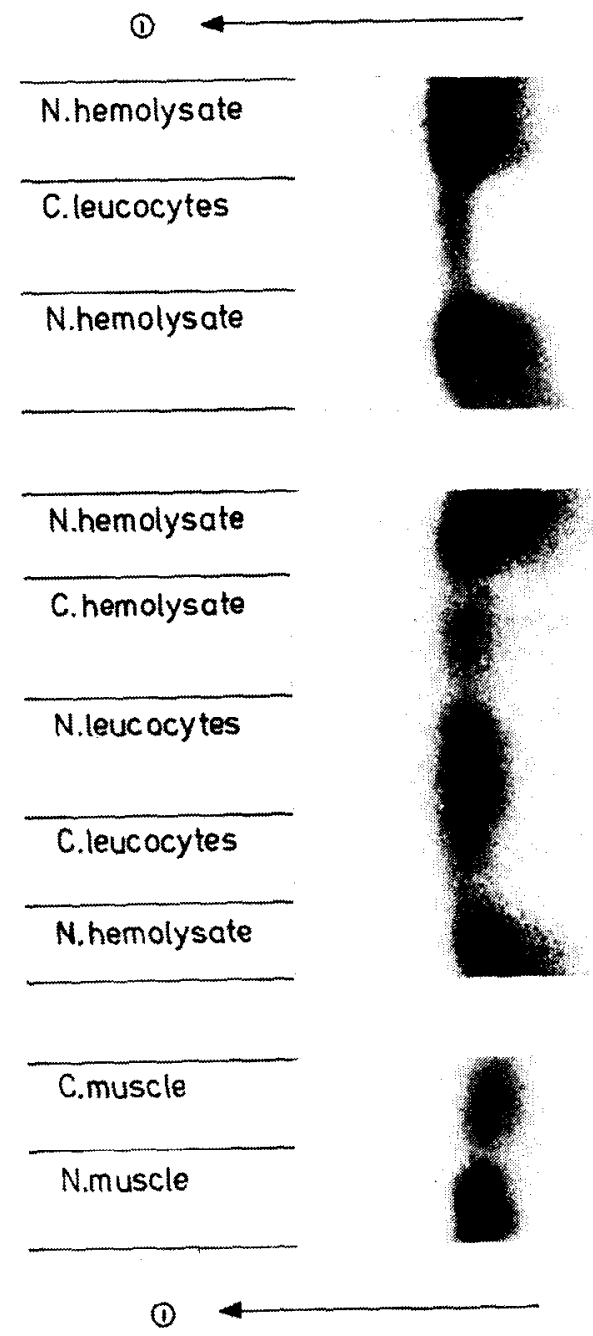

Fig. 3. Electrophoresis of GPI of erythrocytes, leucocytes and muscle tissue, in C, our proband and in normal controls.

erythrocytes (Fig. 4B). From these plots a $K_{\mathrm{m}}$-value for F-6-P of $75 \mu \mathrm{M}$ (normal enzyme) and a $K_{\mathrm{m}}$-value for F-6-P of $72 \mu \mathrm{M}$ (patient's enzyme) can be calculated. For the Michaelis-Menten constants, identical values were obtained. Similarly, $K_{\mathrm{i}}$-values for the competitive inhibitors 2,3-diphosphoglycerate (2,3-DPG) and 6-phosphogluconate (6-PG) were identical for the normal and the patient's enzyme. Fig. 5 shows the inhibition of 2,3-DPG on GPI.

For the normal enzyme $K_{\mathrm{i}}$ for 2,3-DPG of $2.6 \mathrm{mM}$ was calculated (Fig. 5A) and for the patients enzyme this value is about $2.5 \mathrm{mM}$ (Fig. 5B). In case of 6-PG as competitive inhibitor $K_{\mathrm{i}}$ values of $21 \mu \mathrm{M}$ (normal enzyme) and $29 \mu \mathrm{M}$ (patient's enzyme) could be calculated. From these results we can conclude that the kinetic properties of the abnormal enzyme are not different from those of the normal enzyme. 

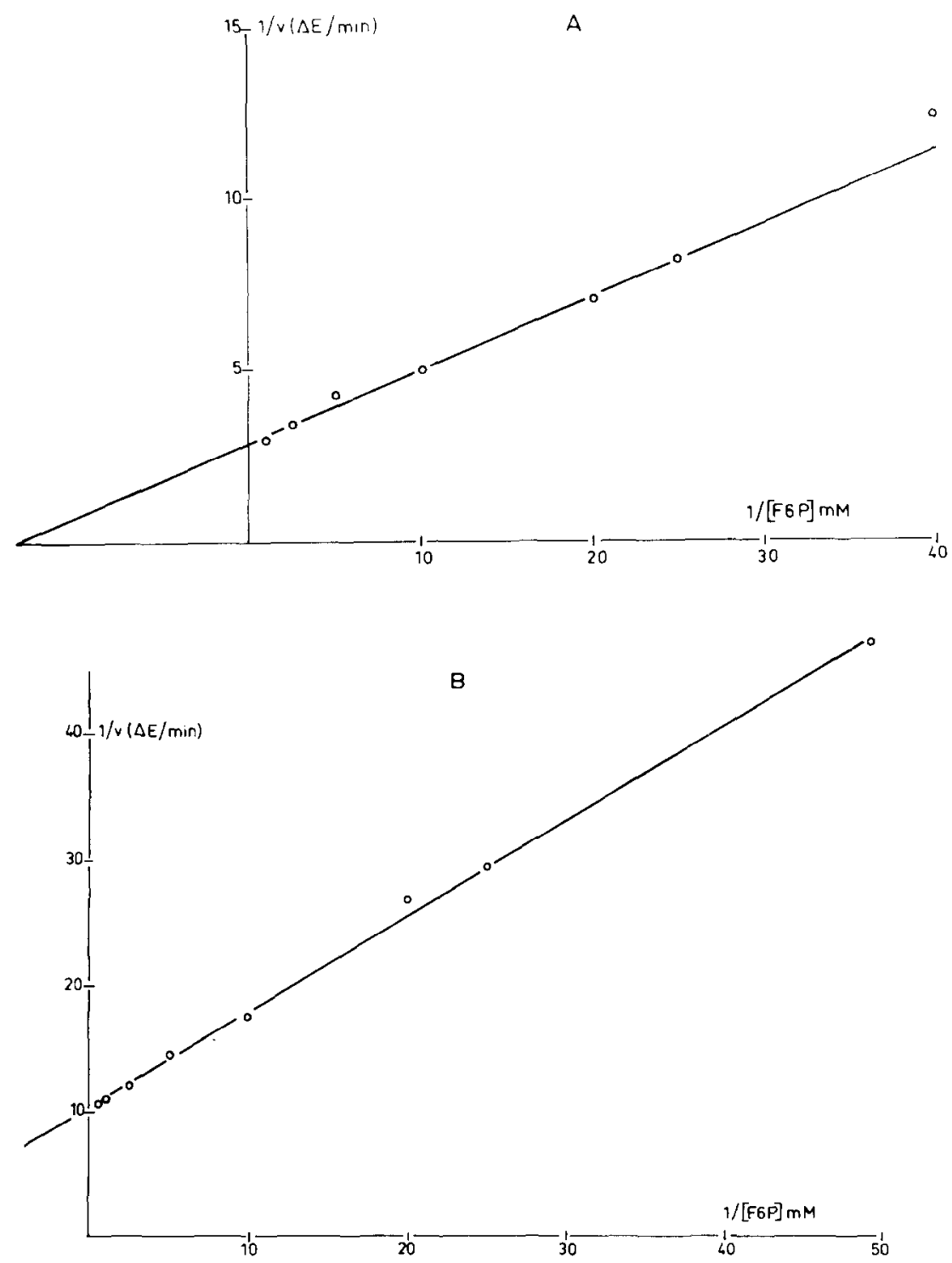

Fig. 4. The $1 / v$ versus $1 /[F-6-P]$ plot at $37^{\circ} \mathrm{C}$ of the enzyme isolated from normal erythrocytes (A) and from the patient's ery throcytes (B). Buffer $5 \times 10^{-2} \mathrm{M}$ TRA, pH $7.2+10 \mathrm{mM}$ EDTA.

\section{Discussion}

The GPI-deficiency described here could be detected in erythrocytes, leucocytes, thrombocytes, liver- and muscle tissue. Based on electrophoretic, and isoelectric-focussing studies, Arnold et al. [19,20] and Payne et al. [21] reported that no tissue specific isoenzymes of GPI exist in man. Although the deficiency of GPI is the same in the tissues so far tested, the increased inactivation of the enzyme is only critical for the red cell. It is only in the erythrocyte with its relatively long lifespan that glycolysis is disturbed by the inactivation 

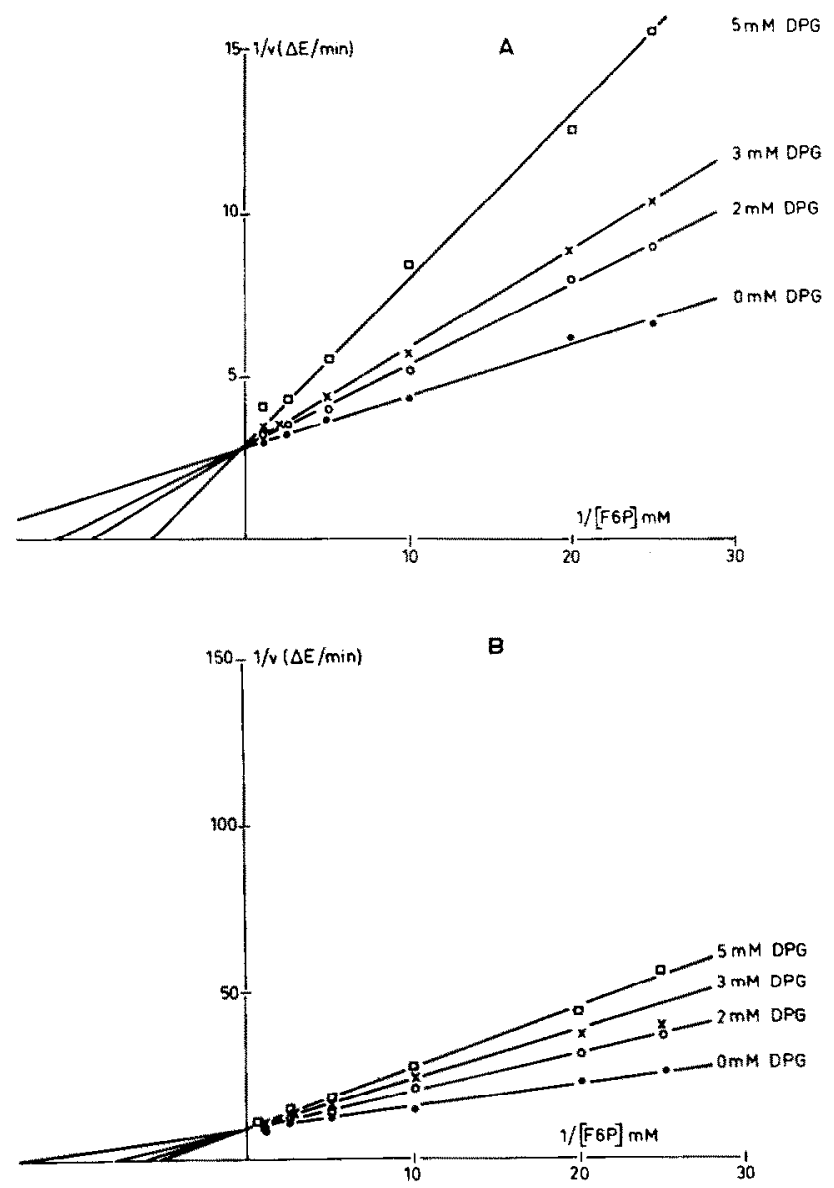

Fig. 5. The $1 / v$ versus $1 /[\mathrm{F}-6-P]$ plot at $37^{\circ} \mathrm{C}$ at different (DPG). The different (DPG) are indicated in the figures. $A$, the plots for the normal enzyme; $B$, the patient's enzyme. Buffer $5 \times 10^{-2} \mathrm{M} \mathrm{TRA}$, pH $7.2+10 \mathrm{mM}$ EDTA.

of GPI. In GPI-deficiency glucose 6-phosphate is increased (see table II). Consequently one would expect inhibition of hexokinase by accumulation of glucose 6-phosphate and therefore reduction of the rate of glycolysis. As pointed out by Löhr [22] the level of glucose 6-phosphate in GPI-deficient patients is not high enough to inhibit hexokinase.

GPI is known to maintain the equilibrium between glucose 6-phosphate and F-6-P. Therefore this enzyme has no regulatory function for glycolysis under normal conditions. In GPI deficiency however the equilibrium between glucose 6-phosphate and F-6-P is not reached, and the kinetic properties of the enzyme are of interest in this particular metabolic situation.

Characterization of the abnormal enzyme showed normal kinetics: normal $K_{\mathrm{m}}$ for F-6-P, normal $K_{\mathrm{i}}$ for 2,3-DPG and 6-PG, normal electrophoretic migration and normal $\mathrm{pH}$-optimum. The only difference found with respect to the normal enzyme is the increased thermal inactivation. Unlike erythrocytic pyruvate kinase anomalies, the polymorphism of GPI defects is not commonly 
manifested by altered enzyme kinetics. In crude homogenates as well as in the partially purified preparations, the apparent Michaelis-Menten constants of the residual GPI, in either erythrocytes or leucocytes, have never been reported to diverge significantly from normal controls. The same applies to the inhibition constants for $6-\mathrm{PG}$ and $2,3-\mathrm{DPG}$.

The enzyme characteristics of the defective enzyme of our proband differ from all other variants presenting normal electrophoretic migration rates: GPI Matsumoto [23], GPI Valle-Hermoso [4], GPI Kentucky [5], and the variants described by Cartier et al. [24] and Müller et al. [3]. GPI Matsumoto [23] exhibited a more acid optimal pH curve and a less pronounced thermal inactivation $\left(30 \%\right.$ residual activity after 60 min heating at $48^{\circ} \mathrm{C}$ ). In GPI ValleHermoso [4] the enzyme deficiency was apparently confined to the erythocyte. In the variant described by Cartier et al. [24] the residual GPI activity in erythrocytes is still twice that observed in our variant.

In the Kentucky variant [5], the residual activity in the erythrocytes is also higher than in our proband $(36-50 \%$ of the normal activity versus $20-25 \%$ in our variant). The thermal inactivation, though not exactly comparable to our results, due to the method differences, seems also more pronounced than in our patient. After $15 \mathrm{~min}$ heating at $50^{\circ} \mathrm{C}$, the normal GPI activity decreased only to $90-95 \%$ of the initial activity; in GPI Kentucky homozygotes, the enzyme is almost completely inactivated. In the variant recently described by Muller [3], the optimal $\mathrm{pH}$-activity curve was shifted to more acid values. All other variants present abnormal electrophoretic migrations.

The results of the enzyme characterisation in the patient, the increased thermolability in both hemolysate and the purified enzyme, and the identity of the enzyme characteristics, so far investigated in both parents, point to homozygous state of a mutant structural allele in our proband. Further genetic studies are in progress.

We propose to give this new enzyme variant the name of GPI-Utrecht.

\section{References}

1 Baughan, M.A., Valentine, W.N., Paglia, D.E., Ways, P.O., Simons, E.R. and De March, G.B. (1968) Blood 32, 236-249

2 Paglia, D.E. and Valentine, W.N. (1974) Am. J. Clin. Pathol. 62, 740-751

3 Müller, E., Marti, H.R., Bach, J., Micheli, J.L. and Gasser, C. (1974) Schw. Med. Wochenschr. 104, $1379-1381$

4 Paglia, D.E.ं, Paredes, R., Valentine, W.N., Dorantes, S. and Konrad, P.N. (1975) Am. J. Hum. Genet. $27,62-70$

5 Hutton, J.J. and Chilcote, R.R. (1974) J. Pediatr. 85, 494-497

6 Beutler, E., Sigalove, W.H., Augus Muir, W., Matsumoto, F. and West, C. (1974) Am. Intern. Med. $80,730-732$

7 Welch, S.G. (1973) Human Heredity 23, 164-174

8 Niessner, H, and Beutler, E. (1973) Biochem. Med. 8, 123-134

9 Minakami, S.C., Suzuki, T., Saito, T. and Yoshikawa, W. (1965) J. Biochem., Tokyo, $58,543-550$

10 Sigma (1971) Sigma Techn. Bull. N. 35-U.V. 12

11 Slein, M.W. (1955) In Methods in Enzymology I (Colowick, S.P. and Kaplan, N.O. eds), p. 299, Academic Press, N.Y., New York

12 Arnold, H., Blume, K.G. and Löhr, G.W. (1974) Pediatr. Res. 8, 26-30

13 Wyss, S.R., Koster, J.F, and Hülsmann, W.C. (1971) Clin. Chim. Acta 35, 277-280

14 Lowry, O.H., Rosebrcugh, N.J., Farr, A.L. and Randall, R.J. (1951) J. Biol. Chem. 193, 265-275

15 Meera Khan, P. and Ratazzi, M.C. (1968) Biochem. Genet. 2, 231-235

16 Welch, S.G. (1971) Human Heredity 21, 467-477 
17 Blackburn, M.N., Chirgwin, J.M., James, G.T., Kempe, T.D., Parsons, T.F., Register, A.M. Schnackerz, K.D. and Noltmann, E.A. (1972) J. Biol. Chem. 247, 1170-1179

18 Detter, J.C., Ways, P.O., Giblett, E.R., Baughan, M.A., Hopkinson, D.A., Povey, S. and Harris, H. (1968) Am. Hum. Genet., Lond. 31, 329-338

19 Arnold, H., Blume, K,G., Engelhardt, R. and Löhr, G.W. (1973) Blood 41, 691-699

20 Arnold, H., Hoffmann, A., Blume, K.G., Engelhardt, R. and Löhr, G.W. (1974) Klin. Wochenschr. 52, 149-151

21 Payne, D.M., Porter, D.W. and Gracy, R.W. (1972) Arch. Biochem. Biophys. 151, 122-127

22 Löhr, G.W. (1972) In Erythrocytes, Thrombocytes and Leucocytes (Gerlach, E., Moser, K., Deutsch, F. and Willmanns, W., eds), p. 182, Thieme Verlag, Stuttgart

23 Nakashima, K., Miwa, S., Oda, S., Oda, E., Matsumoto, N,, Fukumoto, Y. and Yamata, T. (1973) Am. J. Hum. Genet. 25, 294-301

24 Cartier, P., Temkine, H. and Griscelli, C., (1964) Enzymol. Biol. Clin. 10, 439-446 